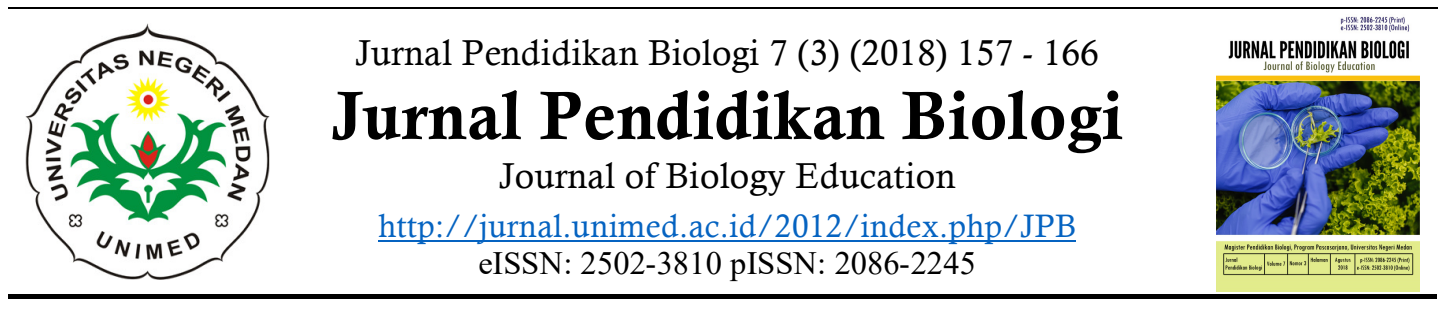

\title{
Penerapan Pembelajaran Problem Based Learning Berbasis Blended Learning terhadap Hasil Belajar Kognitif dan Motivasi Mahasiswa
}

\author{
Setyoko* dan Indriaty \\ Program Studi Pendidikan Biologi, Universitas Samudra \\ Jln. Kampus Meurandeh No. 1, Kecamatan Langsa Lama, Kota Langsa, Propinsi Aceh \\ *Korespondensi: setyoko@,unsam.ac.id
}

DOI: https://doi.org/10.24114/jpb.v7i3.10433

\begin{abstract}
Learning innovation in Higher Education with a scientific approach based learning has been integrated with Information and Communication Technology. This encourages students to solve problems in accordance with the real conditions in the surrounding environment. In addition, it can create self-reliance and learning motivation for students to learn science without any time and place limitation. This study aims to implement scientific approach based learning through the Problem Based Learning model based on Blended Learning in Animal Ecology subjects. This research method is Quasi Experimental Design with Non Equivalent Control Group Pretest-Posttest Design in Experimental groups through combined Problem Based Learning. Blended Learning. The sample of this research is Biology Education students of FKIP Universitas Samudra. The research instrument used cognitive tests in the form of Essay questions and ARCS motivation questionnaires. Qualitative data analysis by testing Validity and Reliability. Hypothesis testing with the prerequisite test for data normality and paired $t$ sample $t$ test. The results of the study obtained the value of $t$ arithmetic $=13.61$ or with Sig (2-tailed) (0.00) $\alpha \alpha(0.05)$ thus Ha was accepted that the significant cognitive learning outcomes of students occurred through learning Blended Learning-based Problem Based Learning. Student learning motivation is categorized into three: very high, high, and medium. The percentage of students in the three categories is 30\%,63.33\%, and $7 \%$ respectively.
\end{abstract}

Keyword: Blended Learning, Cognitive Learning Outcames, Motivation, Problem Based Learning

\section{PENDAHULUAN}

Paradigma melaksanakan perubahan pendidikan melalui dua basis landasan ISCE (International Standar Classification of Education) dan ISCO (International Standard Classification of Occupation) yang terhimpun dalam empat pilar pendidikan: learning to know, learning to do, learning to live together, learning to live. Peningkatkan mutu dalam pembelajaran sains di Perguruan Tinggi diperlukan strategi melalui implementasi pembelajaran yang berbasis pendekatan ilmiah (scientific spproach) sehingga relevan dengan tujuan hakikat sains yaitu; proses sains (scientific processes), produk sains (scientific produck) dan sikap sains (scientific attitudes). Pembelajaran sains abad ke 21 harus menyiapkan mahasiswa dengan berbagai keterampilan dan kecakapan seperti; berpikir kritis, kreatif, inovatif, pemecahan masalah, kolaborasi dan ICT Literacy (National Science Teachers Association NSTA, 2006). 
Kondisi ril pembelajaran di Perguruan Tinggi belum sepenuhnya mencapai kualitas yang ideal, masih terdapat permasalahan pokok yang masih beragam diantaranya; rendahnya pemahaman tentang esensi dari kurikulum dalam sistem pendidikan, kurangnya persiapan dosen dalam menyiapkan pembelajaran, ketidakjelasan pilihan strategi dan metode pembelajaran yang tepat untuk capaian pembelajaran (Sailah, et al., 2014). Hasil observasi pembelajaran sains pada matakuliah Ekologi Hewan di Program Studi Pendidikan Biologi FKIP Universitas Samudra, ditemukan beberapa permasalahan yaitu; (a) Konsepsi belajar mahasiswa sering beranggapan bahwa materi yang dipelajari merupakan pengetahuan bersifat teoritis berdasarkan buku teks yang digunakan sebagai dasar jawaban dalam ujian, sehingga mahasiswa belum terbuka untuk memecahkan masalah dalam pembelajaran, (b) Pertemuan tatap muka perkuliahan relatif singkat dengan materi yang sangat padat, sehingga waktu diskusi mengenai materi perkuliahan sangat terbatas, pembelajaran belum bisa dilakukan secara online oleh mahasiswa.

Kriteria pembelajaran yang baik harus melibatkan perubahan pada mahasiswa seiring dengan waktu dan pengalaman yang dialami mahasiswa (Schunk, 2012). Kondisi belajar yang baik akan menciptakan atmosfer yang positif bagi mahasiswa (Slavin, 2006). Proses pembelajaran harus diakomodasi sesuai dengan dimensi kognitif, afektif dan psikomotor, serta menekankan materi yang dipelajari untuk mencapai tujuan belajar (Fry, et al., 2009). Upaya peningkatan kualitas kegiatan pembelajaran perlu meningkatkan hasil belajar dan motivasi belajar, harus didukung dengan implementasi model pembelajaran yang memiliki karakteristik pendekatan ilmiah, yaitu pembelajaran Problem Based Learning.
Problem Based Learning merupakan model pembelajaran yang menuntut mahasiswa untuk memecahkan permasalahan, sehingga mahasiswa dapat membangun pengetahuannya dan keterampilan berpikir (Arends, 2008). Problem Based Learning mendorong untuk menganalisis masalah berdasarkan situasi nyata (Simone, 2014). Pembelajaran berbasis masalah dapat mempengaruhi kemampuan untuk mencari solusi permasalahan (Facione, 2013). Problem Based learning dapat meningkatkan kemampuan berpikir kreatif dan pemahaman konsep bagi mahasiswa (Yustina, 2016).

Pembelajaran Problem Based Leraning berbasis Blended Learning mendorong mahasiswa dapat menguasai keterampilan hidup (life skill) dengan kemajuan teknologi informasi dan komunikasi, sehingga mahasiswa memecahkan permasalahan dilingkungan nyata sesuai dengan displin ilmu pengetahuan yang dipelajari dengan akses informasi yang luas dan tidak terbatas. Blended Learning merupakan model pembelajaran mengkombinasikan tatap muka dikelas (face to face) dengan penggunaan website secara online. Blended Learning mendukung situasi komunikasi tatap muka dan komunikasi online yang terintegrasi secara optimal sehingga, pengalaman belajar akan mencapai tujuan pembelajaran yang diinginkan (Singh dan Reed, 2001; Garrison dan Vaughn, 2008; dalam Kistow, 2011).

Kombinasi perpaduan pembelajaran Problem Based Leraning berbasis Blended Learning akan membangun keterampilan dan kompetensi mahasiswa melalui pembelajaran berbasis pendekatan ilmiah yang dipadukan dengan kompetensi literasi teknologi informasi dan komunikasi sesuai dengan tuntutan kurikulum di Perguruan Tinggi dengan pembelajaran abad 21 yang menghendaki kompetensi pemecahan 
masalah dan literasi digital yang dapat dimanfaatkan dalam proses pembelajaran. Penelitian ini bertujuan mengimplementasi inovasi model pembelajaran bagi mahasiswa Pendidikan Biologi FKIP Universitas Samudra yang menempuh matakuliah Ekologi Hewan, sehingga dapat memecahkan masalah berdasarkan permasalahan yang ada disekitar berdasarkan landasan pada materi dan konsep teoritis yang dipelajarinya. Mahasiswa dapat mengembangkan kecakapan kompetensi dalam menggunakan pembelajaran online yanng digabungkan dengan tatapmuka sehingga penguasaan komunikasi dan kemampuan menggunakan perangkat (device) teknologi informasi dna komunikasi dapat terarah dan menciptakan suasana pembelajaran yang menuntun mahasiswa untuk kearah pembelajaran. Tercapainya kompetensi yang diharapakan melalui model pembelajaran ini diharapkan akan dapat meningkatkan motivasi dna hasil belajar kognitif.

\section{METODE PENELITIAN}

\section{Tempat dan Waktu}

Penelitian ini akan dilaksanakan pada di Program Studi Pendidikan Biologi Fakultas Keguruan dan Ilmu Pendidikan Universitas Samudra. Waktu pelaksanaan penelitian dilakukan pada bulan Februari sampai dengan Mei 2018.

\section{Populasi dan Sampel}

Populasi pada penelitian ini adalah mahasiswa Pendidikan Biologi Fakultas Keguruan dan Ilmu Pendidikan Universitas Samudra. Mahasiswa yang dipilih pada Semester VI menempuh matakuliah Ekologi Hewan dengan total 60 mahasiswa, yang terdiri dari 2 kelas yaitu unit 1 dan unit 2. Sampel penelitian dipilih berdasarkan teknik Purposive Sampling.
Sampel dalam penelitian ini unit 1 berjumlah 20 orang mahasiswa dan unit 2 berjumlah 30 orang mahasiswa

\section{Rancangan Penelitian}

Penelitian ini merupakan Quasi Experimental Design dengan Non Equivalent Control Group DesignPretest-Posttest pada kelompok Eksperimen. Rancangan penelitian ini bertujuan untuk mengetahui Pembelajaran Problem Based LearningberbasisBlended Learning terhadap peningkatan hasil belajar kognitif dan motivasi belajar mahasiswa pada Matakuliah Ekologi Hewan. Rancangan Penelitian disajikan pada Tabel 1.

\section{Instrumen Penelitian}

Instrumen penelitian untuk mengukur hasil belajar kognitif menggunakan Soal Essay dengan tingkatan $\mathrm{C}_{3}$ sampai dengan $\mathrm{C}_{6}$. Instrumen penelitian untuk mengukur motivasi belajar mahasiswa menggunakan angket ARCS. Perangkat pembelajaran Silabus, RPS, Lembar kerja Mahasiswa, Panduan Praktikum dan Bahan Ajar Ekologi Hewan.

\section{Analisis Data}

Analisis data dilakukan uji validitas, uji reliabilitas, indeks daya beda dan indeks kesukaran soal menggunakan softwereAnates. Analisis data hasil Belajar mahasiswa dianalisis menggunakan uji statistik Paired Sample T Test dengan uji prasyarat Nomalitas data untuk mengetahui distribusi data menggunakan Kolmogorove Smirnov. Analisis data menggunakan softwere SPSS for windows 2.1. Hipotesis penelitian Jika $t_{\text {hitung }} \geq t_{\text {tabel }}$ maka $\left(\mathrm{H}_{\mathrm{o}}\right)$ ditolak dan $\left(\mathrm{H}_{\mathrm{a}}\right)$ diterimaJika $\mathrm{t}_{\text {hitung }}<\mathrm{t}$ tabel maka $\left(\mathrm{H}_{\mathrm{o}}\right)$ diterima dan $\left(\mathrm{H}_{\mathrm{a}}\right)$ ditolak. Analisis data motivasi belajar mahasiswa dianalisis dengan skoring angket ARCS yang tabulasikan dalam bentuk tabel dan grafik berdasarkan interval kategori motivasi belajar pada Tabel 2 . 
Tabel 1. Pretest dan Postest Control Group Design

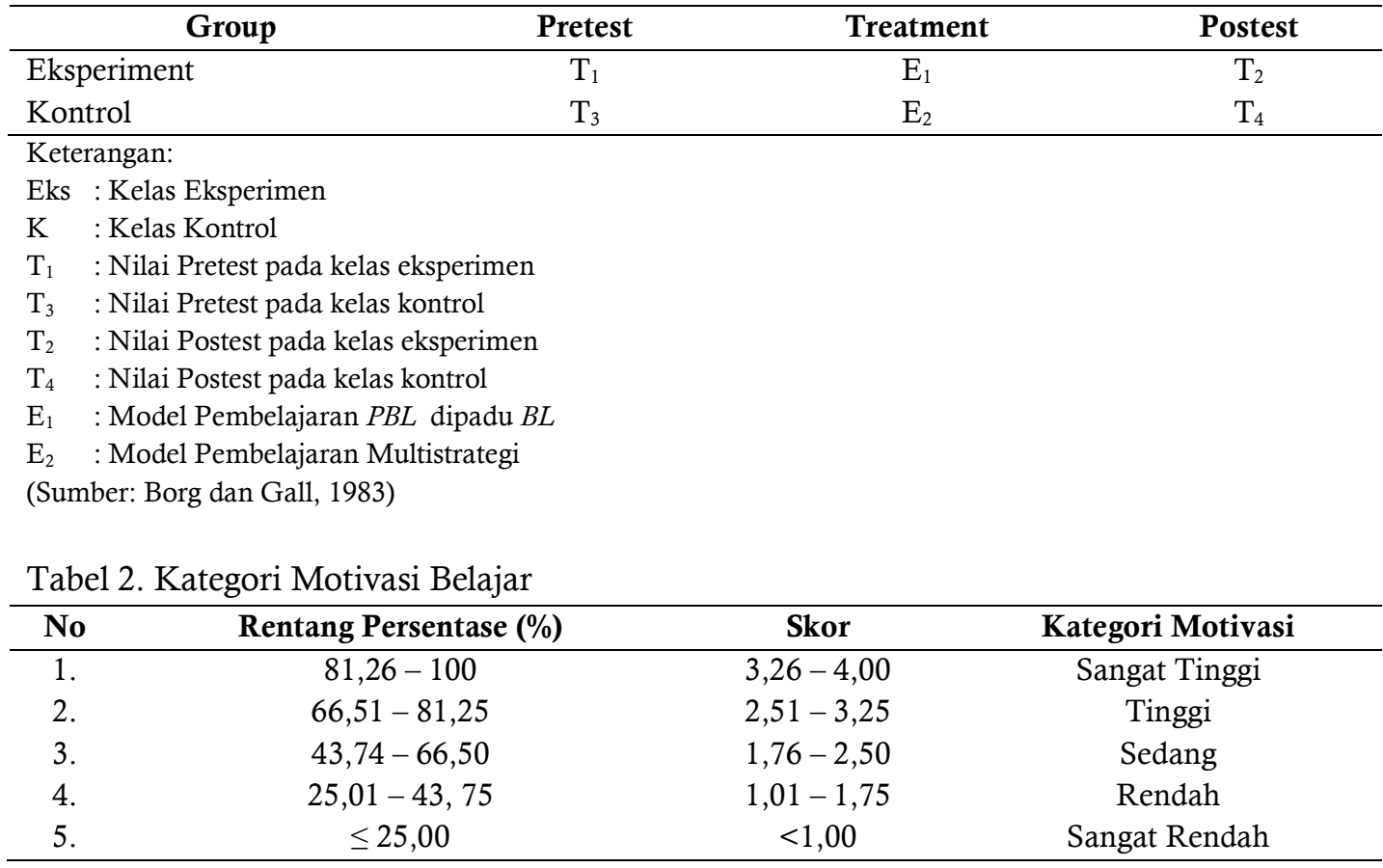

\section{HASIL DAN PEMBAHASAN}

\section{Hasil Belajar Kognitif}

Hasil uji Validitas dan Reliabilitas tes essay yang digunakan dalam tes hasil belajar kognitif mahasiswwa yaitu diperoleh rata-rata nilai; 60,80, Standar Deviasi; 5,01, Validitas; 0,40 (kriteria validitas sedang) dan Reliabilitas; 0,57 (kriteria reliabilitas sedang), dapat dilihat pada Tabel 3.Hasil belajar kogntif mahasiswa pendidikan biologi berdasarkan Pembelajaran Problem Based Learning berbasisBlended Learningpada kelas eksperimen berdasarkan hasil uji Normalitas Data menunjukan Sig $(0,95) \geq \alpha$ $(0,05)$ dengan demikian $\mathrm{H}_{0}$ Diterima, artinya data berdistribusi normal, data dapat dilihat pada Tabel 4. maka dilanjutkan uji Hipotesis menggunakan uji $\mathrm{t}$ Paired sample test, hasilnya rata-rata postest $=79,1 \quad$ setelah diterapkan pembelajaran Problem Based Learning berbasisBlended Learningdan rata-rata pretest $=\quad 60,8$ sebelum diterapkan pembelajaran Problem Based Learning berbasis Blended Learning dengan nilai korelasi 0,154 dengan Sig $(0,415) \geq \alpha$ $(0,05)$ korelasi tidak signifikan. Nilai $t_{\text {hitung }}$ $=13,61$ atau dengan Sig $(2$-tailed $)$ $(0,00) \leq \alpha(0,05)$ demikian $\mathrm{H}_{0}$ ditolak atau $\mathrm{H}_{\mathrm{a}}$ diterimamaka hasil belajar kognitif mahasiswa signifikan terjadi peningkatan melalui Pembelajaran Problem Based Learning berbasis Blended Learning pada kelas Eksperimen. Ringkasan uji t Paired sample test dapat dilihat Tabel 5 dan 6 .

Hasil belajar kogntif mahasiswa pendidikan biologi berdasarkan Pembelajaran multistrategi pada kelas kontrol berdasarkan hasil uji Normalitas Data menunjukan Sig $(0,13) \geq \alpha \quad(0,05)$ dengan demikian $\mathrm{H}_{0}$ Diterima, artinya data berdistribusi normal, data dapat dilihat pada Tabel 7, maka dilanjutkan uji Hipotesis menggunakan uji t Paired sample test, hasilnya rata-rata pretest $=61,5$ dan rata-rata postest $=66,1$ setelah diterapkan pembelajaran multistrategi diperoleh hasil dengan nilai korelasi $-0,25$ dengan Sig 
$(0,288) \geq \alpha(0,05)$ korelasi tidak signifikan. strategi dikelas kontrol. Ringkasan uji $\mathrm{t}$ Nilai $\mathrm{t}_{\text {hitung }}=1,698$ atau dengan Sig $(2-\quad$ Paired sample test dapat dilihat Tabel 8 dan tailed) $(0,106) \geq \alpha(0,05)$ demikian $\mathrm{H}_{0}$ diterima maka hasil belajar kognitif mahasiswa tidak signifikan terjadi peningkatan melalui Pembelajaran multi-

9. Komparasi perbandingan nilai rata-rata hasil belajar pretest dan postest pada kelas Eksperimen dan kelas kontrol dapat dilihat pada Gambar 1.

Tabel 3. Uji Validitas dan Reliabilitas Soal Tes Hasil Belajar

\begin{tabular}{lllc}
\hline Mean & Std.Dev & Validitas & Reliabilitas \\
\hline 60,80 & 5,01 & 0,40 & 0,57 \\
\hline
\end{tabular}

Tabel 4. Uji Normalitas Data Sampel Kelas Eksperimen

\begin{tabular}{lcccccc}
\hline & \multicolumn{3}{c}{ Kolmogorov-Smirnov $^{\text {a }}$} & \multicolumn{3}{c}{ Shapiro-Wilk } \\
\cline { 2 - 7 } Hasil Belajar & Statistic & df & Sig. & Statistic & df & Sig. \\
\hline & 0,105 & 60 & 0,095 & 0,961 & 60 & 0,055 \\
\hline
\end{tabular}

Tabel 5. Paired Sampel Statistic dan Corelation

\begin{tabular}{lllllll}
\hline Hasil belajar & Mean & N & Std. Deviation & Std. Eror & Corelation & Sig. \\
\hline Postest & 79,1 & 30 & 6,227 & 1,137 & \multirow{2}{*}{0,154} & \multirow{2}{*}{0,415} \\
\hline Pretest & 60,8 & 30 & 5,006 & 0,914 & & \\
\hline
\end{tabular}

Tabel 6. Uji T Paired SampleTest Kelas Eksperimen

\begin{tabular}{|c|c|c|c|c|c|c|c|c|}
\hline \multirow{2}{*}{ Hasil Belajar } & \multirow{2}{*}{ Mean } & \multirow{2}{*}{$\begin{array}{l}\text { Std. } \\
\text { Dev }\end{array}$} & \multirow{2}{*}{$\begin{array}{l}\text { Std. } \\
\text { Eror }\end{array}$} & \multicolumn{2}{|c|}{ 95\% Confidence Interval } & \multirow[t]{2}{*}{$t$} & \multirow[t]{2}{*}{ df } & \multirow{2}{*}{$\begin{array}{l}\text { Sig } 2 \\
\text { Tailed }\end{array}$} \\
\hline & & & & Lower & Upper & & & \\
\hline osttest-Pretest & 18,30 & 7,363 & 1,344 & 15,550 & 21,049 & 13,61 & 29 & ,000 \\
\hline
\end{tabular}

Tabel 7. Uji Normalitas Data Sampel Kelas Kontrol

\begin{tabular}{lcccccc}
\hline & \multicolumn{3}{c}{ Kolmogorov-Smirnov $^{\text {a }}$} & \multicolumn{3}{c}{ Shapiro-Wilk } \\
\cline { 2 - 7 } Hasil Belajar & Statistic & df & Sig. & Statistic & df & Sig. \\
& 0,178 & 40 & 0,13 & 0,945 & 40 & 0,050 \\
\hline
\end{tabular}

Tabel 8. Paired Sampel Statistic dan Corelation

\begin{tabular}{lllllll}
\hline Hasil belajar & Mean & $\mathbf{N}$ & Std. Deviation & Std. Eror Mean & Corelation & Sig \\
\hline Postest & 66,10 & 20 & 7,283 & 1,628 & $-0,250$ & 0,288 \\
\hline Pretest & 61,55 & 20 & 7,863 & 1,758 & & \\
\hline
\end{tabular}

Tabel 9. Uji T Paired Sample Test Kelas Kontrol

\begin{tabular}{|c|c|c|c|c|c|c|c|c|}
\hline \multirow[t]{2}{*}{ Hasil Belajar } & \multirow{2}{*}{ Mean } & \multirow{2}{*}{$\begin{array}{l}\text { Std. } \\
\text { Dev }\end{array}$} & \multirow{2}{*}{$\begin{array}{l}\text { Std. } \\
\text { Eror }\end{array}$} & \multicolumn{2}{|c|}{ 95\% Confidence Interval } & \multirow[t]{2}{*}{$\mathbf{t}$} & \multirow[t]{2}{*}{ df } & \multirow{2}{*}{$\begin{array}{l}\text { Sig } 2 \\
\text { Tailed }\end{array}$} \\
\hline & & & & Lower & Upper & & & \\
\hline Posttest- & 4,55 & 11,98 & 2,678 & $-1,056$ & 10,156 & 1,69 & 19 & 0,106 \\
\hline
\end{tabular}




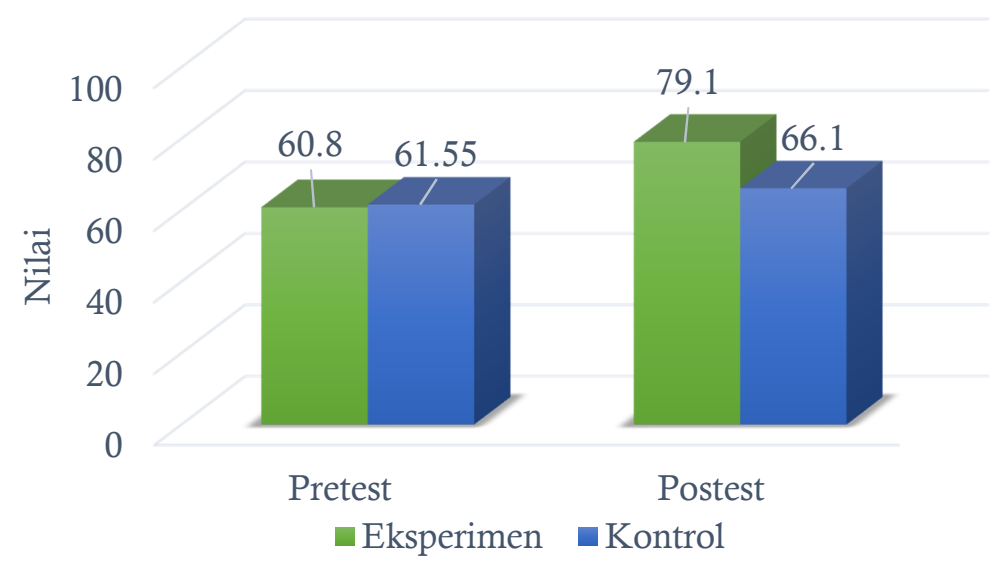

Gambar 1. Perbandingan Nilai rata-rata Hasil Belajar Kelas Eksperimen dan Kontrol

\section{Hasil Motivasi Belajar}

Hasil motivasi belajar mahasiswa pendidikan biologi berdasarkan Pembelajaran Problem Based Learning berbasis Blended Learning pada kelas eksperimen dengan mahasiswa yang memiliki kategori motivasi sangat tinggi berjumlah 9 orang mahasiswa dengan persentase $30 \%$, kategori motivasi tinggi berjumlah 19 orang mahasiswa dengan persentase $63,33 \%$ dan kategori motivasi sedang berjumlah 2 orang mahasiswa dengan persentase $7,00 \%$,dapat dilihat pada Tabel 10. Hasil motivasi belajarmahasiswa pendidikan biologi berdasarkan Pembelajaran Multistrategi pada kelas kontrol dengan mahasiswa yang memiliki kategori motivasi tinggi berjumlah 3 orang mahasiswa dengan persentase $15 \%$, kategori motivasi sedang berjumlah 16 orang mahasiswa dengan persentase $80 \%$ dan kategori motivasi rendah berjumlah 1 orang mahasiswa dengan persentase $5 \%$, dilihat pada Tabel 11.

Tabel 10.Hasil Motivasi Belajar Mahasiswa pada Kelas Eksperimen

\begin{tabular}{cccccc}
\hline No & Rentang (\%) & Skor & Kategori motivasi & $\sum$ & Persentase (\%) \\
\hline 1. & $81,26-100$ & $3,26-4,00$ & Sangat Tinggi & 9 & 30,00 \\
2. & $66,51-81,25$ & $2,51-3,25$ & Tinggi & 19 & 63,33 \\
3. & $43,74-66,50$ & $1,76-2,50$ & Sedang & 2 & 7,00 \\
4. & $25,01-43,75$ & $1,01-1,75$ & Rendah & 0 & 0 \\
5. & $\leq 25,00$ & $<1,00$ & Sangat Rendah & 0 & 0 \\
\hline
\end{tabular}

Tabel 11.Hasil Motivasi Belajar Mahasiswa pada Kelas Kontrol

\begin{tabular}{cccccc}
\hline No & Rentang (\%) & Skor & Kategori motivasi & $\sum$ & Persentase (\%) \\
\hline 1. & $81,26-100$ & $3,26-4,00$ & Sangat Tinggi & 0 & 0 \\
2. & $66,51-81,25$ & $2,51-3,25$ & Tinggi & 3 & 15 \\
3. & $43,74-66,50$ & $1,76-2,50$ & Sedang & 16 & 80 \\
4. & $25,01-43,75$ & $1,01-1,75$ & Rendah & 1 & 5 \\
5. & $\leq 25,00$ & $<1,00$ & Sangat Rendah & 0 & 0 \\
\hline
\end{tabular}




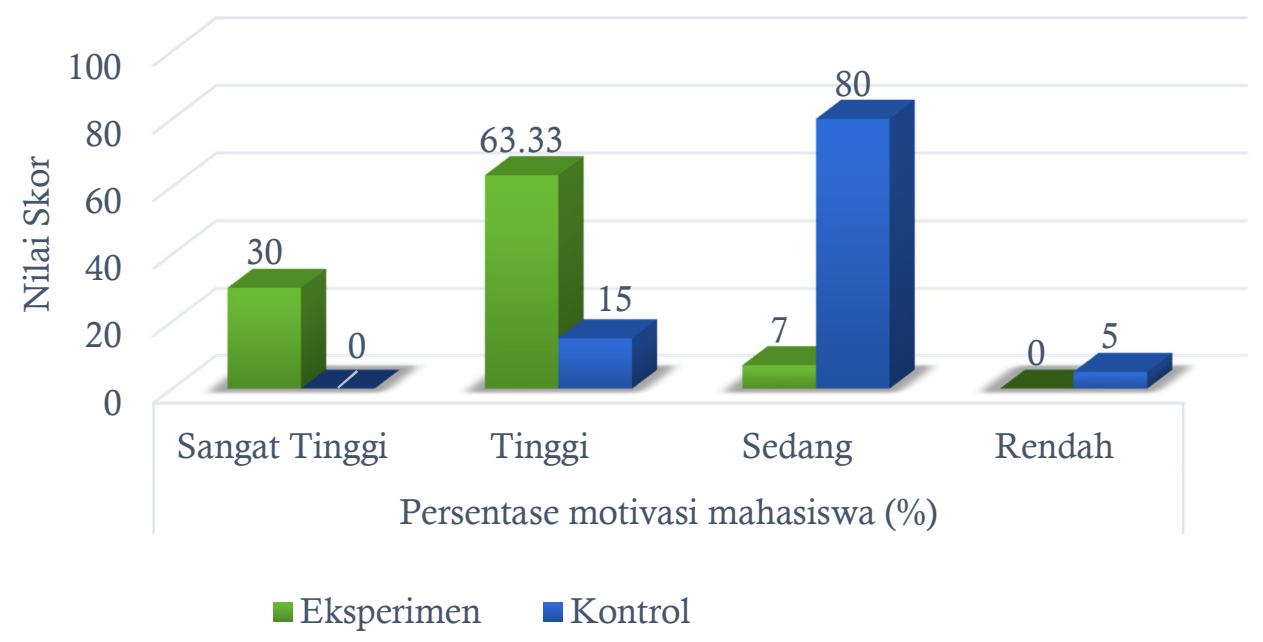

Gambar 2. Perbandingan Persentase Motivasi Belajar Kelas Eksperimen dan Kontrol

\section{Pembahasan}

Penerapan pembelajaran problem based learning berbasisblended learning memberikan peningkatan signifikan terhadap hasil belajar kognitif mahasiswa pendidikan Biologi pada matakuliah Ekologi hewan. Evaluasi tes yang diberikan pada mahasiswa pendidikan biologi antara kelas eksperimen dan kontrol terdapat perbedaan, hasil belajar mahasiswa pendidikan biologi dikelas eksperimen terdapat pemahaman kemampuan berpikir kognitif mahasiswa dalam hal memecahkan soal berdasarkan tingkat analisis sampai dengan tingkat evaluasi. Pembelajaran blended learning memiliki peningkatan dapat meningkatkan prestasi akademik rata-rata bila dibandingkan dengan siswa dalam lingkungan belajar tatap muka (Saritepeci dan Cakir, 2015).

Kemampuan dasar mahasiswa pendidikan biologi dalam mempelajari matakuliah ekologi hewan terbangun dari proses pembelajaran yang dilakukan secara aktif dikelas dan dilapangan pada saat praktikum. Problem based learning merupakan pendekatan berpusat pada mahasiswa memiliki keterkaitan dengan masalah dan pengetahuan sebelumnya
(Savery dan Duffy, 2001). Hasil belajar kognitif merupakan sebagai hasil-hasil kegiatan atau proses memperoleh pengetahuan melalui pengalaman sendiri. Kognitif berorientasi pada kemampuan berfikir yang mencakup kemampuan intelektual yaitu kemampuan memecahkan masalah yang menuntut mahassiswa untuk menghubungkan dan menggabungkan gagasan atau prosedur yang sebelumnya dipelajari untuk memecahkan masalah (Yamin, 2006).

Penerapan model pembelajaran kelas Eksperimen mahasiswa selalu diberikan tugas-tugas berbasis problem based learning pada setiap pertemuan yang berbasis blended learning, sehingga pembelajaran yang dilakukan mendorong mahasiswa membangun proses berpikir untuk memecahkan masalah dalam pembelajaran sesuai dengan teori dan keadaan nyata. Sudarman (2007), problem based learning pendekatan pembelajaran yang menggunakan masalah dunia nyata untuk belajar dengan menerapkan proses berpikir kritis dan keterampilanmemecahan masalah dalam memperoleh pengetahuan. Pembelajaran dilakukan dengan memanfaatkan media online melalui 
website google classroom yang dipergunakan mahasiswa dalam aktifitas belajar diluar kelas untuk membahas materi yang sudah dibahas dikelas sehingga mahasiswa lebih dapat beraktivitas setiap saat untuk belajar. Pembelajaran blended learning memiliki efek positif dalam meningkatkan hasil belajar (Perez, et al., 2011). Blended learning memberikan respon postif bagi mahasiswa, meskipun tidak berpengaruh langsung pada pembelajaran yang ditentukan (Ngana, et al., 2017). Aktivitas belajar mahasiswa mengalami peningkatan dengan adanya Blended Learning. Mahasiswa dapat secara mandiri mengakses sumber-sumber belajar yang telah disiapkan dalam website. Mahasiswa dapat melakukan diskusi dengan dosen dan mahasiswa lain secara terjadwal maupun secara mandiri (Suwono, 2013).

Kegiatan pembelajaran yang diterapkan dikelas mahasiswa melakukan praktikum lapangan yang kegiatannya menuntun mahasiswa melakukan dengan penyelidikan secara mandiri sehingga terbangun pengetahuan melalui proses yang dilakukan. Pembelajaran Problem Based Learning akan menunjang pembelajaran yang efektif untuk proses berpikir tingkat tinggi, membantu mahasiswa memproses informasi, membantu mahasiswa membangun pengetahuannya sendiri (Munasir dan Anshori, 2010).Problem based learning memberikan wewenang untuk melakukan penelitian, mengintegrasikan teori dan praktik, dan mengaplikasikan pengetahuan dan keterampilan untuk membangun solusi terhadap suatu permasalahan (Savery, 2006).Problem based learning menyajikan berbagai permasalahan yang autentik dan bermakna kepada mahasiswa, yang berfungsi untuk mendorong melaksanakan investigasi dalam penyelidikan (Arends, 2008).
Pemanfaatan media website dalam pembelajaran ekologi hewan problem based learning berbasis blended learning memberikan sebuah kegiatan pembelajaran yang menarik dan disenangi oleh mahasiswa pendidikan biologi, adanya perbedaan motivasi belajar antara kelas eksperimen dengan kelas kontrol. Pada kelas eksperimen mahasiswa lebih termotivasi dalam mempelajari materi setelah perkuliahan dikelas dan dapat mengeksplorasi pengetahuannya pada saat berdiskusi didalam forum group online. Indikator keberhasilan untuk hasil belajar mahasiswa dalam pembeljaran blended learning ditunujkan oleh karakateristik mahasiswa dan rancangan pembelajaran (Kintul, Zhu, dan Edmond, 2017). Melalui penerapan model blended learningdikelas eksperimen dapat membantu dalam hal meningkatkan motivasi mahasiswa dalam belajar. Peningkatan motivasi tersebut masih kembali kedalam motivasi intrensik mahasiswa itu sendiri. (Ramakrisnana, 2012). Pembelajaran Blended Learning memotivasi mahasiswa untuk menyelesaikan tugas tepat waktu dan memfasilitasi perkembangan keterampilan belajarmahasiswa dan pencapaian kompetensi (Suwono, 2013).Motivasi belajar daya penggerak dalam diri pembelajar yang menimbulkan kegiatan belajar, yang menjamin kelangsungan dari kegiatan belajar dan yang memberikan arah pada kegiatan belajar, sehingga tujuan belajar dapat tercapai. Problem based learning pembelajaran yang efektif dan memiliki memberi penjelasan dan memberikan efek positif yang menumbuhkan minat bagi peserta didik dalam mempelajari materi (Grady, et al., 2012). Penerapan Problem Based Learnning dapat menghasilkan lebih banyak solusi untuk memecahkan suatu masalah, meningkatkan motivasi, dan kerja sama 
dan meningkatkan keterampilan berpikir kritis siswa (Semerci, 2006).

\section{KESIMPULAN}

Kemampuan hasil belajar kognitif mahasiswa berdasarkan Uji hipotesis diperoleh Nilai $\mathrm{t}_{\text {hitung }}=13,61$ atau dengan Sig $(2$-tailed $)(0,00) \leq \alpha(0,05)$ demikian $\mathrm{H}_{\mathrm{a}}$ diterima maka hasil belajar kognitif mahasiswa signifikan terjadi peningkatan melalui Pembelajaran Problem Based Learning berbasis Blended Learning. Motivasi belajar mahasiswa memiliki kategori motivasi sangat tinggi berjumlah 9 orang mahasiswa dengan persentase $30 \%$, kategori motivasi tinggi berjumlah 19 orang mahasiswa dengan persentase $63,33 \%$ dan kategori motivasi sedang berjumlah 2 orang mahasiswa dengan persentase $7,00 \%$.Saran penelitian selanjutnya diperlukan integrasi model pembelajaran yang lebih inovatif berbasis Blended Learning dalam menunjang proses perkuliahan dikelas, sehingga kompetensi pembelajaran yang diharapkan sesuai dengan capaian pembelajaran abad 21.

\section{UCAPAN TERIMAKASIH}

Ucapan terimakasih penulis ucapkan kepada Direktorat Jendral Penguatan Riset dan Pengembangan Kemenristek Dikti dan Civitas Universitas Samudra dan pihak terkait yang telah memberikan dana ataupun bantuan lainnya dalam penelitian ini dalam program Hibah Penelitian Dosen Pemula Tahun 2018.

\section{DAFTAR PUSTAKA}

Arends, R. (2008). Learning to Teach. Penerjemah: Helly P dan Sri M. New York: McGraw Hill Company.

Borg, W., \& Gall, M. (1983). Educational Research an Introduction. New York and London: Logman
Facione, P. (2013). Critical Thinking: What It Is and Why It Counts. California: Measured Reason and The California Academic Press.

Fry, H., Steve, K., \& Stephanie, M. (2009). The Handbook for Teaching and Learning in Higher Education. New York dan London: Routledge.

Kintul, M. K., Zhu, C., \& Edmond, K. (2017). Blended learning effectiveness: the relationship between student characteristics, design features and outcomes. International Journal of Educational Technology in Higher Education, 14 (7), p 2-20.

Kistow, B. (2011). Blended learning in higher education: A study of a graduate school of business, Trinidad and Tobago. Caribbean Teaching Scholar, 1 (2), p 115-128.

Munasir \& Anshori, S. (2010). Pengintegrasian Problem Bassed Learning dan Pendekatan Group Investigation. Jurnal Kependidikan Interaksi, 5 (5), p 1-9.

National Science Teachers Association. 2006. Induction Programs for the Support and Development of Beginning Teachers

Ngana, O., Tangb, T., Chanc, A., Daisy, M., \& Mei K. (2017). Blended Learning in Anatomy Teaching for Non-Medical Students: An Innovative Approach to the Health Professions Education. Journal Health Professions Education, 4 (1), p 149-158.

Perez, V., Lopez, M., \& Lazoro, R. (2011). Blended learning in higher education: Students perceptions and their relation to outcomes. Journal Computers and Education, 56 (1), p 818-826.

Ramakrisnana, P., Yahya, Y., M. Nor, H., \& Azlan. (2012). Blended Learning: A Suitable Framework For E-Learning In Higher Education. Procedia - Social and Behavioral Sciences. The 3rd International Conference on eLearning ICEL 2011 (p 513-526) Bandung: UPI

Sailah, I., Tresna, D. K., I Made, S., SP Mursid., Endrotomo., Sylvi, D., Syamsul, A., Liliana S., Ludfi, D., Jumhur., Sri P., Lien, H., Henny, K., Emmy, H., Ridwan, R. T., Evawany \& Nafiron, M. (2014). Buku Kurikulum Pendidikan Tinggi. Jakarta: Direktorat Pembelajaran dan Kemahasiswaan, Direktorat Jendral Pendidikan Tinggi, Kementrian Pendidikan dan Kebudayaan

Sartepeci, M., \& Cakir, H. (2015). The Effect of Blended Learning Environments on Student's Academic Achievement and Student Engagement: A Study on Social 
Studies Course. Journal Education and Science, 4 (177), p 203-216.

Savery, J., \& Duffy, T. (2001). Problem Based Learning: An instructional model and its constructivist framework. CRLT Technical Report, 16 (01), p 77-81.

Savery, J. (2006). Overview of Problem-based Learning: Definitions and Distinctions. The Interdisciplinary Journal of Problem-based Learning, 1 (1), p 9-20.

Schunk, D. (2012). Learning Theories An Educational Perspective. Boston: Pearson Education, Inc.

Semerci, N. (2006). The Effect of Problem-Based Learning on The Critical Thinking of Students In The Intellectual and Ethical Development Unit.

Slavin, R. (2006). Educational Psycology: Theory and Practice. Boston: Pearson Education, Inc.

Simone. (2014). Problem-Based Learning in Teacher Education. International Journal of Humanities and Social Science, 4 (12), p 54-62
Sudarman. (2007). Problem Based Learning: Model Pembelajaran untuk Mengembangkan dan Meningkatkan Kemampuan Memecahkan Masalah. Jurnal Pendidikan Inovatif, 2 (2), p 68-73.

Suwono, H. (2013). Aktivitas belajar mahasiswa calon guru Melalui penerapan Blended Learning Menggunakan website berbasis moodle. Prosiding Seminar Nasional Biologi IPA 2013 (p153-160. Surabaya: UNESA.

Yamin. (2006). Strategi Pembelajaran Berbasis Kompetensi. Jakarta : Gaung Persada Pers

Yustina. (2016). Pemikiran Kreatif dan Pemahaman Konsep Mahasiswa Pendidikan Biologi dalam Pembelajaran IPA Melalui Problem Based Learning (PBL). Prosiding SEMIRATA Bidang MIPA 2016 (p 231-233) Palembang: UNSRI. 